\title{
MOBILE CLUBBING: IPOD, SOLITUDE AND COMMUNITY
}

\author{
Ruud Kaulingfreks \\ University of Humanistics, Netherlands \\ kaulingfreks@luna.nl \\ Samantha Warren \\ University of Surrey, UK \\ s.warren@surrey.ac.uk
}

\begin{abstract}
We take a philosophical look at solitude and community through the phenomenon of the iPod. We observed that this tiny technological wonder is at one and the same time a possibility of shutting oneself off from the world in real or imagined solitude, and a way we can find ourselves in the company of like-minded others, sharing experiences as a member of a community. The first part of the article deals with how iPod enables solitude. Second, we look at the other side of the coin and explore what it means to be in a community of iPodders. Finally, we describe a fascinating phenomenon that, for us, exemplifies the concepts of solitude and community.
\end{abstract}

Key words: Solitude. Community. Mobile technologies.

\section{CLUBISMO MÓVEL: IPOD, SOLITUDE E COMUNIDADE}

\begin{abstract}
Resumo
Observamos, sob a perspectiva filosófica, a solitude e a vida em comunidade a partir do fenômeno do iPod. Argumentamos que esta pequena maravilha tecnológica é, ao mesmo tempo, a possibilidade de isolar-se do resto do mundo numa solidão real ou imaginada, e uma maneira de encontrarmo-nos na companhia de outros curtidores, compartilhando experiências como membro de uma comunidade. A primeira parte do artigo trata de como o iPod permite a solitude. Em segundo lugar, olharemos para o outro lado da moeda e exploraremos o que significa estar em uma comunidade de iPodders. Finalmente, descrevemos um fenômeno fascinante que, para nós, exemplifica os conceitos de solitude e comunidade.
\end{abstract}

Palavras-chave: Solidão. Comunidade. Tecnologias moveis.

\section{Introduction}

In this paper we take a philosophical look at solitude and community through the phenomenon of the iPod. The need to be alone yet be part of a group is perhaps one of the most primeval human attributes and we find it fascinating that this tiny technological wonder is at one and the same time a way of shutting oneself off from the world in real or imagined solitude, and a way we can find ourselves in the company of like-minded others, sharing

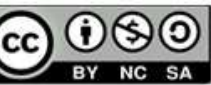

Esta obra está licenciada sob uma Licença Creative Commons Atribuição 4.0 Internacional (CC BY-NC-AS 4.0). 
experiences as part of a community. Of course we are not suggesting that it is the iPod alone which conjures up these effects - the iPod is only a possibility because of the development of connective technologies, new file formats, storage capabilities and processing speeds. Furthermore, the role of sound, music and silence in social life is an inextricable factor in how the iPod works as a technology of togetherness and aloneness and we will return to these ideas below. The idea of one's own personal musical soundscape is also not new. Since the Sony Walkman was introduced over 25 years ago, we have enjoyed the delights of losing ourselves to a favourite tune on say, a crowded train or during a long and boring hike home, and even before that ghetto blasters were carried around on shoulders blaring out the soundtrack to its porter's life. So what makes the iPod different? Why should this particular piece of music technology represent such an interesting site at which to philosophise about solitude and community in contemporary social life?

In a sense then, iPod is nothing new but everything new. We contend that it is an iconic site where high quality digital sound enabled by smarter file formats, high speed connectivity through the Internet and personal, customisable music on-the-go converge and so for us it is the perfect place to think about how and why people come together or remain alone. To this end and throughout the article, we mobilise a variety of conceptual resources from the philosophies of art and of Being and proceed as follows. First we consider the longevity and significance of the 'soundscape' as an organizing principle of human societies and discuss how the iPod seemingly separates us from the world, enabling us to enter into our own personal soundscape. This first part deals with how iPod enables solitude. Second, we look at the other side of the coin and explore what it means to be in a community of iPodders. Here we dwell a while on the ideas of Gadamer (1986) and Nancy (1991) to examine how iPods, and indeed music, help us to be social beings. Finally, we describe a fascinating phenomenon that, for us, exemplifies the concepts of solitude and community. This is the 'mobile club' - a gathering of people, usually organised as a 'flash mob' event ${ }^{1}$ who meet to dance to the music playing on their own iPods. Solitary individuals quite literally dancing to a different tune - together - but the onlooker only hears silence. We end the article by raising the possibility that the iPod sensitises us to possibilities for alternative communities that escape the tyranny of exclusion and totalitarianism.

\footnotetext{
1 'Flash mob' is defined by Wikipedia as: "a large group of people who assemble suddenly in a public place, do something unusual for a brief period of time, then quickly disperse." The invitations to take part are usually distributed by mobile phone text messages and word of mouth and a key characteristic of these gatherings is that few people know each other.
} 
But first we should say a few words about ourselves and the perspectives we bring to bear on these topics. One of us is indeed a philosopher, but the other is a scholar of organization studies and so we are as interested in the philosophical meanings iPod might engender as we are in the ways those meanings are mobilised and brought together - in other words, the way iPod organizes our understandings and experiences of solitude and community.

\section{All by myself: soundscapes and solitude}

As we've already recalled, the idea of a soundscape is not new - far from it. The ability to choose what one listens to and shuts out of aural reach has a long history and it is this enduring character that makes it so interesting. As a matter of fact many fundamental elements of civilization are built on our capacity to hear, and produce, sounds. Take work, for example; in the early European Middle Ages monks in the cloisters introduced clock bells to mark the beginning and ending of prayers. The silence of religious work was encapsulated in two acoustic signals marking the beginning and end of prayer. Later the clock was used to mark the beginning and ending of work for each of the crafts guilds producing a cacophony of bell-ringing. So sound was the precondition for organizing and organization and labor was something to be done between sound signals; bells and later sirens. By encapsulating work in between sound signals, organizations form their own sound identity or soundscape. And in between the signal's silence the sound of the work itself is produced and further distinguished from the daily sounds of the city. Of course, in the white-collar environment the opposite applies, work should be done in silence and as little noise from the other should be heard.

Our point here is that each soundscape marks out the boundaries of where one set of social relations begins and ends - in between sirens the machines produce their noise and work is done in a specific soundscape different from free time. Importantly, this soundscape is organized and controlled as opposed to the uncontrolled street noises and it is this notion of control that we want to focus on here with regard to the iPod. Indeed, the mere distinction between 'sound' and 'noise' is a sign of one's own soundscape - the pleasant, acoustic signals we want we call 'sound' and the unwanted or dysfunctional ones we call 'noise' and try to reduce or get rid of. So we are continually creating our own personal soundscapes. At home we create quiet 'cosy' sounds and keep loud machines away. The materials we use in our living rooms absorb sound and soften noise. We continually organize the sound in soundscapes of wanted or pleasurable sounds and discard the unwanted noise. Even our 
bodies seem to have good and bad sounds or healthy or unhealthy. Physicians literally listen to us in auscultations and can determine our wellbeing by the sound of it.

So we might say that when we put on our iPod, we enter a unique aural world, control our soundscape and enter a kind of 'virtual reality' as an escape from (or change to) the activity or task we are performing. We are using the iPod to organize sound that marks out one form of existence from another. But is this so? In the end the iPod is not much different from reading a book or, for that matter the newspaper, or watching a film in a darkened cinema - activities we do in the solitude of our own mind. The idea of escaping reality can be seen as a reluctance to understand the new and in this sense we can compare iPod to the reactions of laypeople after the introduction of books in Europe. It is said that people gathered around to see monks reading in silence! The novelty of watching people completely imbued in a world of their own, detached from the world around them was a spectacle in itself. So, perhaps the iPod is not an escape from reality and it does not bring us into virtual reality in any sci-fi sort of way. It just provides the means to engage in our own reveries and mindful activity - like philosophical thinking, for example.

Of course, we could argue that iPod transports us into a fantasy universe but music has always done that and art even more so. We get carried away by the performance of a play or in viewing a painting, we dream in the concert hall, the novel transports us into the magic world of words, etc... and we love it to the extent that we actually search out these experiences. We consider a life without art - without the possibility of fantasy and dream - an impoverished world and are shocked when we hear of societies where art has no place. According to the German philosopher Nietzsche, art affords us disconnection from the concrete materiality of our present surroundings which we need in order to understand the world (NIETZSCHE, 1967, v. 3, p. 464). He reminds us that art gives us the necessary distance to comprehend the world we are otherwise imbued in. As a result of this 'retreat to art' iPod closes our senses to an inward world of contemplative sound but it also forms a visual barrier to social engagement. When we see the white earplugs we know the other is not available. But should she be? At this moment we are writing this and we are not available for our colleagues or friends. If one of our children demands our attention we make it very clear that he should wait till we finish work. In the same way, iPod shuts the social world out and gives the signal that we do not want social contact, but this sounds harsher than it is. 


\section{Download and shuffle: between individual and the social}

The iPod and its associated technologies also allow a new and different kind of individuation. As well as playing our favourite music, audio books, radio programmes and so on, it allows us to customise its content in ways unheard of in the past. Instead of passively accepting the decisions of the record label to include certain music tracks in a particular order, for instance, we can choose to download and store just the tracks that we actually want from a collection. Then we can store them in a genre-classified group if we so choose, mix them up using the shuffle feature for variety, or carefully order them in a set sequence (playlist) that fits the building momentum of a workout, for example. But to what extent do these activities really represent acts of personal, solitary choice? Are we truly able to shape these technologies in ways that mark us out as individuals? The very fact that everyone is doing it means that perhaps the act of owning and using an iPod is enough to connect us in some way to others who we know like doing the same things.

Undoubtly the iPod is meant for personal use. That is, to individually listen to its content and shut off the signals from our surroundings - the acoustic signals at least. But this does not necessarily mean solitude. It enables a retraction from the world into a kind of concentration that still is highly sociable since we are listening to music others also listen to and even playlists are published on the Internet for others to share. So how individual is personal? IPod makes a strong personalisation possible and in this sense is a kind of individualisation gadget. But is still an individualisation of arranging existing components. The content is publicly available and as we have already said: are we really doing something very individualistic and solitary by listening to it?

And then there is the sheer choice of material that we can listen to on our iPods. Music is a small part of the itunes website, for example, with podcasts making up a significant feature of iPod culture. Although you don't need an iPod to listen to a podcast, the two are often thought of synonymously and represent another way that customisable iPod content can be downloaded. Podcast programmes can be subscribed to, or single episodes downloaded relating to a huge range of interests, on subjects as diverse as gardening tips, 'bedroom DJ' dance mixes and higher level chemistry courses, or spoken novels for instance.

This leads us to the point where we move away from listening, and nearer to producing music and sound and so to acts that are more social than solitary. In order to make music, or produce a podcast programme, one needs a listener in mind - someone who will 
incorporate it into their own personal library and use it to shut themselves off from the world in the ways we have outlined above. So we cannot say that the iPod is truly a solitary technology. In the next section we will explore what it means to be part of the iPod-enabled community, or indeed iPod culture more broadly.

\section{All together now: iPod and community}

So far, we've considered the isolating individuating characteristics of the iPod, looking at the disconnectivity of personal soundscape and the customisation of content as routes to a separation from the social for the listener. Ironically, this customisation and decentralised production capability led us to the point where we returned to the idea that iPod might be more social than it first appears. Staying with the idea of podcasts and i-mixes that sowed this seed, we can easily see that a community of listeners can assemble around a particular programme, episode or mix. When we download our episode or buy our tracks, we can see how many others are doing the same - are we alone in our choice, or do we join a larger group of seemingly like-minded people? How does knowing we are making similar choices to others out there in cyberspace make us feel? Here we begin to see how even in the most decentralised and disconnected milieu of the Internet and digital sound human beings have found a way to share and to build community. Why? Because art always creates community. As we have already mentioned, the iPod is a device related to art. It plays music - popular or classical. It enables theatre plays, literature, some play movies and of course the thing itself has won many design prizes. So, again perhaps some comparisons with ideas from philosophies of art will help us here.

According to Gadamer (1986), art creates its own community in the sense that it invites us to participate. Because a work of art is something outside the functional world and because we can't $d o$ anything with a work of art besides appreciate or dislike it, we are forced to engage with it. Since we can't integrate it in our daily activities, the work of art invites us in its own realm. Marcel Duchamp's idea to use the Mona Lisa as an ironing board illustrates this idea: the painting is not useful for anything other than its own existence (and certainly not terribly suited to being an ironing board!) Of course we can shut ourselves out and not listen to the music or not see the painting, but if we engage with it, that is if we sense it, we are immediately sucked into it and have to participate in it for its own sake. Gadamer (1986, p. 24) uses the comparison with the spectators at a tennis match cricking their necks back and 
forth as they watch the ball. No-one can avoid playing along with the game. The work does not accommodate itself in our world but it is $u s$ that are driven into the realm of the work.

This means that art creates its own world and as already argued by Heidegger (2002) it brings us to a specific space and time: we forget normal time and are transported into the place of the play or story. This is especially strong with music; it makes us forget our sorrows. If we don't forget them we can't engage or appreciate art or music because we are simply too distracted. Put another way, the rhythm of the music grabs us and we are literally 'out of this world' and iPod - as a technology of art - helps this to happen.

Art also creates identity and difference. Sure, art grabs us and brings us in its realm but it does not create a uniform world. Everybody swings with the music but each listener reacts differently, everyone sees the same play but we all value it differently and actually we see different things.

The work leaves the person who responds to it a certain leeway, a space to be filled in by himself. (Gadamer 1986, p. 26)

This space is what we talk about later on when we discuss our experiences after the film or the play, or when we take our earplugs off... we dwell upon the work in the specific way the work demands of us. Art gathers us together and challenges us to make the work our own, that is, to engage with it. All art gives us a sense of belonging in the appreciation of it. We can't argue about personal taste - each to their own opinion - but shared taste brings us together and this is especially the case with music. For example, the dancers at the party feel bonded by their love for the rhythms, they dance together and can't stand aside. It is literally ecstasy or stepping outside of ourselves (ekstasis). The partygoers are dance, they become the music in communio, that is - fused together.

So iPod brings us together firstly in the recognition of a shared passion for music in general. Seeing the white earplugs is already a recognition of this fact. But there is also the bonding brought about by the type of music: listening to John Coltrane or U2 brings us together with all other lovers of those artists. Although in the moment there is no physical evidence of sharing, there is always the possibility of communicating, more or less - just as we share a favourite writer while we still read in solitude. But there is more. What we want to suggest from here on however, seems a little weird but - we think - rings true. Gadamer speaks of a community in the sense of consciously sharing a taste or a fascination for a particular work of art. We want to argue that a community doesn't necessarily need to be 
consciously aware of itself; it doesn't need to have an identity and iPod reminds us of that fact.

\section{Singular plural?}

A philosopher that has been receiving considerable attention in continental Europe in the last decade is the Frenchman Jean Luc Nancy. He has been writing about communities for some considerable time and together with Italian thinker Giorgio Agamben and French philosopher Alain Badiou, he is considered an exponent of new social thinking. According to him there is always community:

Community is given to us with being and as being, well in advance of all our projects, desires and undertakings. At bottom, it is impossible for us to lose community. (Nancy 1991, p. 35)

This sounds rather a grand statement since politicians and social commentators alike seem to be continually worried about community or rather, a lack of community. Surely communities can't be that easy? But that is precisely Nancy's point. We continually forget the given of the community and make it an object of organization. By doing that we tend to create ersatz communities that can't disguise the fact they are not really communities. If groups of people who are supposedly communities (neighborhoods, work teams, the 'friends' on social networking sites, for instance) are actually artificially constructed ones, then more realistically, all we are engaged in is a discussion about inclusion and exclusion and deciding who is allowed or disallowed in the community; we have politicized community which according to Nancy invariably leads to totalitarism. We have to start realizing that our existence, our being, is from the onset, a being with others. We don't exist detached from others and can only be because there are others. So from the outset we are in a relation.

At this point we seem to have drifted a long way from cycling through the tracks on our iPod and shutting out the world while we cycle on our bicycle to work! But for Nancy, individuality is like the atoms in a whole. They exist in relation to each other. We can only realize we are individuals because there is another. The very fact that we can customise our iPods, choose our own soundscape and make our own mixes automatically shows to us that other configurations are possible - there must be others too. But what's important here is that we don't need to know who these others actually are exactly, just knowing they exist reminds us we are not alone. 
But this 'being with others' doesn't mean we are all alike. It doesn't mean there is no identity or individuality at all. Being is also (and always) diversity as we hope to have shown above. If we weren't different then we would have no concept of alternative possibilities and therefore no idea of our human connectedness. It is because of alterity that we position ourselves as different. We are not all the same and we take an individual position vis-à-vis the other. But we need the other in order to take that position so we are always in a relation (it is impossible to think without the relation). The other is not a radical 'Other' but already is part of us. It makes our identity. Considering what other possibilities there might be make us up since we can consider just what it is that makes us into $u s$. We are together or singular but in alteration or plurality. So Nancy concludes that being is always singular plural.

Nancy is not advocating for nostalgia and a return to an original community (or communitas) of organic relations where the community forms a homogenous whole and directs the relations and identity of its members. This is certainly not a return to Rousseau's happy savages that have been corrupted by society (societas) and destroyed by the mechanical relations of the division of labour as was put forward by Tönnies (2003). Nancy actually rejects the idea of a transformation from community into society driven by a social contract. That lost community never existed, it is a romantic myth that merely serves to ground our idea of society as having developed from something which we do not really remember.

Society was not built on the ruins of a community. It emerged from the disappearance or the conservation of something - tribes or empires - perhaps just as unrelated to what we call 'community' as to what we call 'society'. So that community, far from being what society has crushed or lost, is what happens to us - question, waiting, event, imperative - in the wake of society (Nancy, 1991, p. 11).

The point here is that because we exist with others in a singular plural there is no central identity to society. A common trait to community or society can only exist as an exclusion. The idea of a community of commonality only makes sense if others don't share the trait that the others have in common. Community should be without identity; it should be inoperative. There is no organization of community. Community means we recognize the lack of communal traits and goals and accept we always are together in a singular plurality.

Being in common has nothing to do with communion, with fusion into a body, into a unique and ultimate identity that would no longer be exposed. Being in common means, to the contrary, no longer having, in any form, in 
any empirical or ideal place such a substantial identity, and sharing this (narcissistic) lack of identity. (Nancy, 1991, preface xxviii).

So what does all this philosophical talk leads to? Nancy opens up a way to think about the social in a radically different manner and we think that iPod is an excellent example of what he means. He asks us to think of inoperative communities, the gathering together of people that have no communal traits but are bonded to each other in the recognition of being with others. Of course, there is some commonality between iPodders in that they all have an iPod (!) but that is where the similarities end. This means realizing community is not something to be organized, produced, and segmented into markets as is so often the end desire, but should be seen as emergent situations that are continually changing and altering. Being in common or being with others is demonstrated precisely where there is no communal identity, nor organized communality. It comes to the fore or emerges in the unexpected situations of being together in singular plurality. A group waiting in line, for instance, or dancing to their own individual music: moments where we recognize we are together but still separated and certainly not homogenous; we are together without forming a club or organization. All attempts to organize communities, to give them a stable identity are exactly the opposite of community and negate the being with others that always exists because these attempts are based on exclusion.

\section{Inoperative community: mobile clubbing}

IPod in this sense enables inoperative communities of gathering - of singular plural as we shall see is the case, according to us, in mobile clubbing or before that, in flash mobs. As we have seen there is communality in listening to our own music in solitude while knowing that others also listen to maybe different music from the same source. We recognize a shared interest or passion; we are together for a brief instance but still are by ourselves.

To conclude this article, then, we leave you with the strange phenomenon that fuelled our interest in these issues and also serves as a perfect example of how iPod simultaneously facilitates community and reinforces solitariness - the 'mobile club'. The concept of 'mobile clubbing' was originally borne from the 'silent disco' experiment at the 2005 Glastonbury festival in the UK and the Dutch Parade festival in 2003. Problems with late night noise from the festival tents led to the organisers issuing wireless headphones to festival go-ers which were tuned into the DJ. Revellers danced as they would normally do - except to anyone else 
entering, the tent was silent: hence the name 'silent disco'. The 'mobile clubbing' idea takes this further through the activity of flash mobbing (see above), for example in and 2006 and 2007 groups of several thousand people converged on London's mainline railway stations and the Tate Modern gallery to dance 'in silence' to music through their headphones - but this time, it was their own music on their own iPods (HARPER, 2006; EDWARDS, 2007 and www.mobileclubbing.com).

Within the confines of these pages it is hard to convey the almost comical spectacle of the mobile club - a simple search for 'mobile clubbing' on 'YouTube' will reveal several camera phone video clips of the bizarre scenes for you to see for yourself. It is fascinating to watch each dancer, initially self-conscious and looking around for acknowledgement from other people, begin to lose their feelings of individuality and dance - along with everyone else - as if no-one else was there. With Nancy in mind, we suggest that this loss of self is only possible because of the knowledge that as we dance we are not alone. But the clubbers are not part of the whole either - how can they be when they are all moving to a different beat? The experience of taking part is reflected on below by a participant and nicely encapsulates some of the philosophical points we have made in this article:

Despite many people's attempts to make it a social occasion, the fact that everyone was listening to their own music meant that people kept getting drawn back into themselves, however much they tried to be with their friends and have a collective experience. The dancing didn't only transform the space and stop people in their tracks - it transformed codes of behaviour, not only for the dancers but the onlookers too. (Harper, n.d)

The last words of this quotation capture something of the character of the event as a 'show stopper' - such a strange thing to encounter in many ways - imagine hurrying through a train station during rush hour and coming across several hundred people wearing iPods swaying, jerking and leaping about to nothing. They all seem to be there together yet none are actually interacting - do they even know each other at all? How did they come to be there? And what is their purpose?

The phenomena of 'mobile clubbing' seems to us to bring together many of the philosophical issues we have discussed above with regard to human beings' need for community, solitude, music and soundscape. It also calls into question traditional notions of 'public space' and challenges the kind of activities that are permissible in spaces that are supposed to be freely used by all. It also reminds us of the power of people who come together for a shared purpose, and in that sense it is a powerful signal to states and 
governments that we are active agents and can bring about social demonstrations more easily than ever given the technologies in our hands today. Of course, this is an eccentric and benign manifestation of power and we might be critical of such frivolity as drawing attention away from pressing issues that need our communal engagement and demonstration. But it is not really the job of philosophy to concern itself with the political ramifications of human action, rather to ponder what conditions lead to the desire to do such things in the first place.

What we claim the mobile club does do is disrupt traditional notions of what it means to be in community, together, alone and individual - and it does so through the power of art, enabled by iPod and its technologies. With Nancy in hand we can see that iPod serves as a vehicle of combining solitude and togetherness, letting inoperative communities form as a demonstration of emergent power but without a preconceived political goal. It is this bonding in solitude that according to us makes iPod such a fascinating device and so much more than just the possibility of listening to our own music so as to shut ourselves out from our fellow commuters on the morning train while we still struggle to wake up. Retracted in individuality we still may be in relation with others. Nancy makes it very clear that a community without identity is a powerful antidote to all those political rhetorics that wants us to be part of a strong 'community of freedom' in whatever guise that may take - and that if we are not with it we automatically are against it. We end on our point that the way to understand the diversity of societies today is to think about what it means to be singular plural. Mobile clubbing may in the end have broader political implications we can see at this moment. And all this thanks to iPod...

\section{REFERENCES}

EDWARDS, G. New Platforms for Dance. Londondance.com, 2006. Available in: <http://www.londondance.com/content.asp?CategoryID=1629>. Accessed: 12-10-07.

GADAMER, H.G. The relevance of the Beautiful and other essays. Edited by Robert Bernasconi, Cambridge: Cambridge University Press, 1986.

HARPER, G (n.d.). Stationary Dancing. Londondance.com, 2006. Available in: <http://www.londondance.com/content.asp?CategoryID=1629\&ArticleID=29783>.

HEIDEGGER, M. The Origins of the work of Art. In: Off the Beaten track. Edited and translated by: Julian Young and Kennet Haynes. Cambridge: Cambridge University Press, 2002.

NANCY, J.L. The inoperative Community. Mineapolis: University of Minnesota Press, 1991. 
NIETZSCHE, F. Die fröliche Wissenschaft (Gaya Scienza). In: Kritsche Studienausgabe Herausgegeben von Giorgio Colli und Mazzino Montinari, v. 3. Berlin: de Gruyter, 1967.

TÖNNIES, F. Community and Society. New York: Dover publications. 2003. 